УДК 681.12

DOI: http://dx.doi.org/10.20535/2219-3804182018122235

V. N. Fedorov ${ }^{1}$, candidate of technical sciences, N. I. Stefan ${ }^{2}$, candidate of technical sciences, M. A. Yatchenko ${ }^{3}$, student

\title{
ALGORITHMIC METHOD OF THE TURBO FLOWMETER ACCURACY INCREASING
}

Ua У статті обговорюєтья можливість підвищення точності вимірювання витрати рідини турбосиловим витратоміром. У якості причин похибок розглядаються дві - наявність сталого моменту тертя в осях підвісу індикаторної турбіни та нестабільність характеристик пружного елементу. Першу із цих похибок пропонується усунути, провівши вимірювання у разі двох сталих фіксованих значеннях кутової швидкості обертання силової турбіни, після обробки відповідним чином результати вимірювань. Точне значення витрати у випадку нестабільності пружних властивостей пружини може бути отримано на основі ідентифікації параметрів індикаторної турбіни у перехідному режимі між вказаними кутовими швидкостями обертання силової турбіни.

Ru В статье обсуждается возможность повышения точности определения расхода жидкости турбосиловым расходомером. В качестве причин погрешностей рассматриваются две - наличие постоянного момента трения в осях подвеса индикаторной турбины и нестабильность характеристик упругого элемента. Первую из указанных ошибок предлагается устранить, проведя измерения при двух постоянных фиксированных значениях угловой скорости вращения силовой турбины, обработав соответствующим образом результаты измерений. Точное значение расхода в случае нестабильности упругих свойств пружины может быть получено на основе идентификации параметров индикаторной турбины в переходном режиме между указанными угловыми скоростями вращения силовой турбины.

\footnotetext{
${ }^{1}$ NTUU «Igor Sikorsky Kyiv Polytechnic Institute», Department of Theoretical Mechanics

${ }^{2}$ NTUU «Igor Sikorsky Kyiv Polytechnic Institute», Department of Theoretical Mechanics

${ }^{3}$ NTUU «Igor Sikorsky Kyiv Polytechnic Institute», Faculty of Aircraft and Space Systems
} 


\section{Introduction}

The accuracy of physical quantities measurement is the most relevant in any branch of science and technology. The technique of mechanical quantities measuring, in particular the flow of liquids and gases, is no exception.

The possibility of the accuracy increasing of a turbo-flowmeter designed to measure the mass flow of liquid and gaseous substances is considered in the article.

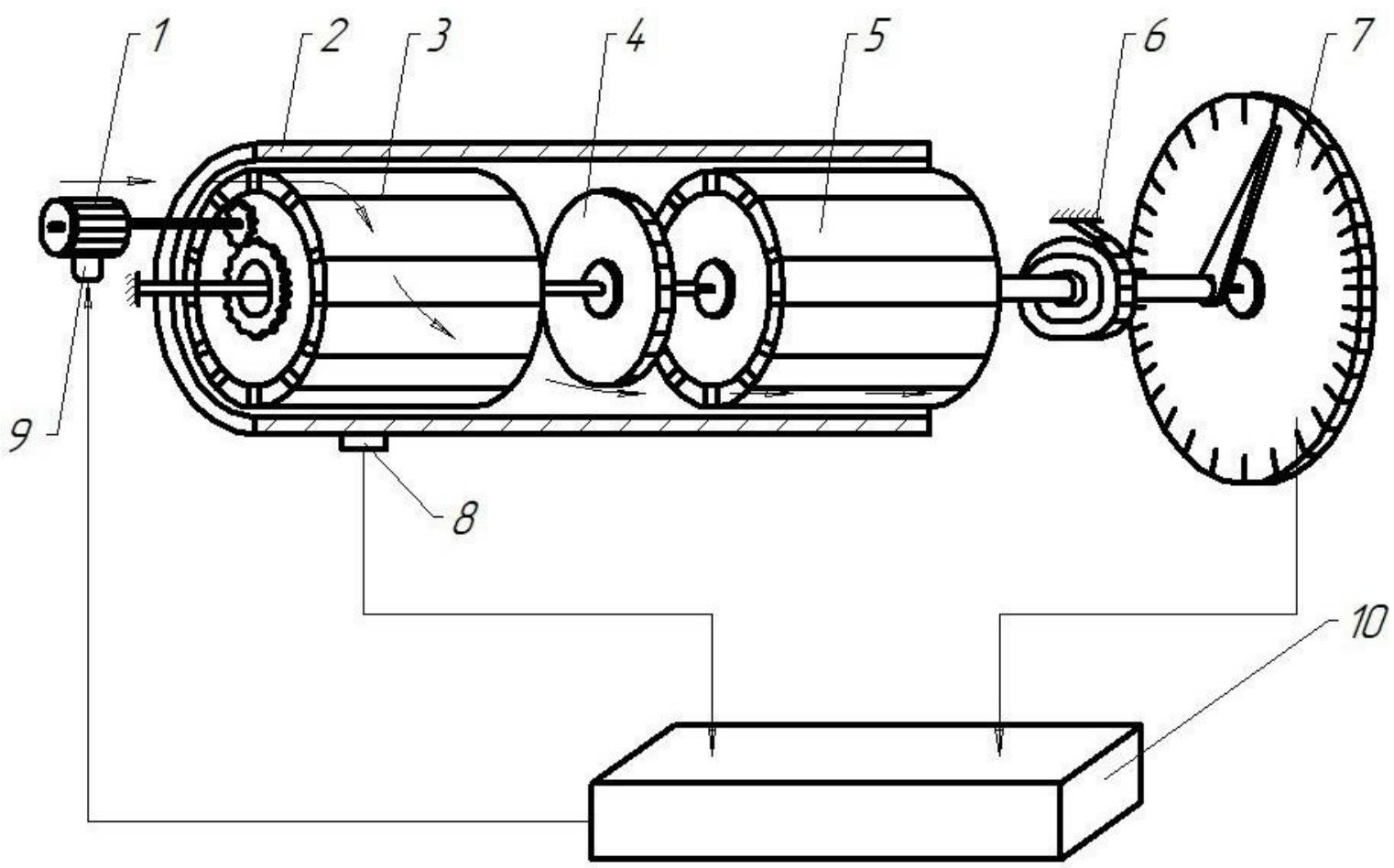

Fig. 1. A schematic diagram of a flowmeter

Fig. 1 shows a schematic diagram of a flowmeter. An excitation turbine 3 , having fluid paths separated by partitions parallel to the turbine axis, is installed inside the pipeline 2. The excitation turbine is driven by the electric motor 1 with angular velocity $\omega$ and twists the fluid, which acquires the screw motion shown by the arrows.

Further, the liquid runs into the stationary turbine 5, passing through the stationary disk 4, which reduces the viscous coupling between the turbines. Under the action of fluid moving at the entrance to the stationary turbine along the helical line, the stationary turbine fixed to the spring 6 rotates by an angle $\varphi$, proportional to the mass flow rate of the liquid. The counting device 7 determines the dependence of the stationary turbine rotation $\varphi=\varphi(t)$ on time.

Frictional forces torque in the stationary turbine supports and instability of spring stiffness are the main sources of mass flow errors of the turbo-power flowmeter. To reduce the errors of the turbo-flowmeter, it is proposed in [1] to use the so-called compensation measurement method, schemes with continuous rotation of both turbines, both interconnected and rotating autonomously. In [2], 
a special design of a torque-transmitting node between turbines ensuring an increase in the accuracy and expansion of the measurement range is proposed. Flowmeters schemes with different design execution are considered in [3].

The frictional forces torque in the indicator turbine supports and the spring stiffness instability are the main sources of errors in mass flow measuring of the turbo-power flowmeter [1].

\section{Problem Statement}

A method for determining the mass flow rate of liquids by a turboflowmeter, which eliminates the errors generated by the presence of a constant frictional moment in the axes of the stationary turbine suspension and the instability of the spring elastic properties, is considered in the article.

\section{Main part}

The equation of a stationary turbine motion 5 has the form

$$
I_{5} \ddot{\varphi}+\alpha_{5} \dot{\varphi}+c \varphi=\omega r_{c}^{2} Q_{M}-M_{M},
$$

where $I_{5}$ - the moment of inertia of a stationary turbine relative to the axis of rotation;

$\alpha_{5}$ - coefficient of a stationary turbine viscous friction of a liquid;

$c$ - spring 6 rigidity;

$\varphi-$ is the rotation angle of the stationary turbine;

$\omega-$ is the angular velocity of the fluid rotation caused by the excitation turbine 3;

$r_{c}$-is the average radius of the turbine excitation channels 3;

$Q_{M}$ - flow rate mass $\left(Q_{M}=\frac{d m}{d t}\right)$

$M_{M}$ - moment of friction in stationary turbine bearings 5 .

It is quite obvious that in the case of a constant friction moment $\mathrm{M}_{M}$ in stationary turbine bearings $\left(M_{M}=\right.$ const $)$, the dependence of the rotation angle $\varphi$ on the flow $Q_{M}$ in the steady state $(\ddot{\varphi}=0, \dot{\varphi}=0)$

$$
\varphi=\frac{\omega r_{c}^{2}}{c} Q_{M}-\frac{1}{c} M_{M},
$$

will contain an error caused by the moment of friction.

To compensate for this error, it is proposed to measure the rotation angle of a stationary turbine at two different constant values $\left(\omega_{1}-\right.$ const, $\omega_{2}-$ const $)$ of the angular velocity of the excitation turbine rotation. Then, assuming that during the measurement time the mass flow $Q_{M}$ does not change, we obtain the dependence (2) in the form 


$$
\begin{aligned}
& \varphi_{1}=\frac{\omega_{1} r_{c}^{2}}{c} Q_{M}-\frac{1}{c} M_{M} ; \\
& \varphi_{2}=\frac{\omega_{2} r_{c}^{2}}{c} Q_{M}-\frac{1}{c} M_{M},
\end{aligned}
$$

where $\varphi_{i},(i=1,2)$ are the rotation angles of the stationary turbine at the values of the angular velocity of the excitation turbine rotation $\omega_{i},(i=1,2)$.

$$
Q_{M}=\frac{\varphi_{1}-\varphi_{2}}{\omega_{1}-\omega_{2}} \cdot \frac{c}{r_{c}^{2}} .
$$

To eliminate the error caused by the instability of the spring elastic properties, it is proposed to analyze the transient process of changing the angular velocity of the excitation turbine from its initial value $\omega_{1}$ to the final value $\omega_{2}$ and to carry out a procedure for the parametric identification of unknowns.

Let us compose and solve the equation of the excitation turbine motion.

Due to the theorem of the angular momentum change, the equation of the excitation turbine motion has the form

$$
\frac{d}{d t}\left[\left(I_{3}+m r_{c}^{2}\right) \omega\right]=-\alpha_{3} \omega+M_{\mathrm{en}},
$$

where $I_{3}-$ is the moment of inertia of the excitation turbine;

$m$ - is the rotating liquid mass;

$\alpha_{3}$-is the viscous friction coefficient of the excitation turbine of liquid;

$M_{\text {en }}$ - is the moment applied by the engine to the rotation axis of the excitation turbine.

Transforming equation (5) to the form

$$
\dot{\omega}+\frac{\alpha_{3}+r_{c}^{2} Q_{M}}{I_{3}+m r_{c}^{2}} \omega=\frac{M_{\mathrm{en}}}{I_{3}+m r_{c}^{2}},
$$

we obtain its solution

$$
\omega=\left(\omega_{1}-\omega_{2}\right) e^{-\beta t}+\omega_{2},
$$

where $\omega_{1}-$ is the initial value of the angular velocity of the excitation turbine

$$
\begin{aligned}
& \omega_{2}=\frac{M_{\mathrm{en}}}{\alpha_{3}+r_{c}^{2} Q_{M}}-\text { is the final value of the angular velocity of the } \\
& \beta=\frac{\alpha_{3}+r_{c}^{2} Q_{M}}{I_{3}+m r_{c}^{2}} .
\end{aligned}
$$

Substituting expression (7) into equation (1), we obtain:

$$
I_{5} \ddot{\varphi}+\alpha_{5} \dot{\varphi}+c \varphi=\left[\left(\omega_{1}-\omega_{2}\right) e^{-\beta t}+\omega_{2}\right] r_{c}^{2} Q_{M}-M_{M}
$$


We transform the system of equations (3) to the form

$$
M_{M}=r_{c}^{2} Q_{M} \cdot \frac{\omega_{1} \varphi_{2}-\omega_{2} \varphi_{1}}{\varphi_{2}-\varphi_{1}}
$$

and substitute it in the expression (8):

$$
I_{5} \ddot{\varphi}+\alpha_{5} \dot{\varphi}+c \varphi=\left(\omega_{1}-\omega_{2}\right) r_{c}^{2} Q_{M} e^{-\beta t}+\frac{\varphi_{2}\left(\omega_{1}-\omega_{2}\right)}{\varphi_{2}-\varphi_{1}} r_{c}^{2} Q_{M}
$$

Dividing expression (10) by $I_{5}$, and introducing the notation

$$
\frac{\alpha_{5}}{I_{5}}=2 n ; \quad \frac{c}{I_{5}}=k^{2} ; \quad \frac{\left(\omega_{1}-\omega_{2}\right) r_{c}^{2} Q_{M}}{I}=A ; \quad \frac{\varphi_{2}\left(\omega_{1}-\omega_{2}\right)}{\left(\varphi_{2}-\varphi_{1)}\right.} \cdot r_{c}^{2} Q_{M}=B,
$$

we write (10) in the form

$$
\ddot{\varphi}+2 n \dot{\varphi}+k^{2} \varphi=A e^{-\beta t}+B
$$

Parametric identification involves comparing the real motion of a stationary spring with the movement of its mathematical model, given, for example, in the form of an analytical solution of the motion differential equation. Let us solve the equation (12). This solution, depending on the relation between the parameters $n$ and $k$, will have the form:

- the case $n>k$

$$
\begin{aligned}
\varphi & =\dot{\varphi}_{1} \frac{e^{p_{1} t}-e^{p_{2} t}}{p_{1}-p_{2}}-\varphi_{1} \frac{1}{p_{1}-p_{2}}\left(p_{2} e^{p_{1} t}-p_{1} e^{p_{2} t}\right)+ \\
& +A \frac{1}{p_{1}-p_{2}}\left[\frac{\left(p_{1}-p_{2}\right) e^{-\beta t}}{\left(p_{1}+\beta\right)\left(p_{2}+\beta\right)}+\left(\frac{e^{p_{1} t}}{p_{1}+\beta}-\frac{e^{p_{2} t}}{p_{2}+\beta}\right)\right]+ \\
& +B \frac{1}{p_{1}-p_{2}}\left[\frac{p_{1}-p_{2}}{p_{1} p_{2}}+\left(\frac{e^{p_{1} t}}{p_{1}}-\frac{e^{p_{2} t}}{p_{2}}\right)\right],
\end{aligned}
$$

where $p_{1}=-n+\sqrt{n^{2}-k^{2}} ; p_{2}=-n-\sqrt{n^{2}-k^{2}} ; \varphi_{1}$-is the stationary turbine rotation angle at the value of angular velocity of the excitation turbine rotation $\omega_{1}$; $\dot{\varphi}_{1}-$ is the initial angular velocity.

- the case $n=k$

$$
\varphi=\left(\dot{\varphi}_{1}+n \varphi_{1}-\frac{A}{n-\beta}-\frac{B}{n}\right) t \cdot e^{-n t}+\varphi_{1} e^{-n t}+\frac{B}{n^{2}}\left(1-e^{-n t}\right)
$$

- the case $n<k$ 


$$
\begin{aligned}
\varphi & =\frac{A e^{-\beta t}}{(n-\beta)^{2}+\omega^{2}}-\frac{A}{\omega} \cdot \frac{e^{-n t}}{(n-\beta)^{2}+\omega^{2}}[(n-\beta) \sin \omega t-\omega \cos \omega t]+\frac{B}{n^{2}+\omega^{2}}- \\
& -\frac{B e^{-n t}}{\omega\left(n^{2}+\omega^{2}\right)}[n \sin \omega t-\omega \cos \omega t]+\left[\frac{1}{\omega}\left(\dot{\varphi}_{1}+n \varphi_{1}\right)+\frac{2 A n}{(n-\beta)^{2}+\omega^{2}}+\right. \\
& \left.+\frac{B}{\omega\left(n^{2}+\omega^{2}\right)}\right] e^{-n t} \sin \omega t+\left[\varphi_{1}-\frac{2 A n}{(n-\beta)^{2}+\omega^{2}}-\frac{2 B}{n^{2}+\omega^{2}}\right] e^{-n t} \cos \omega t,
\end{aligned}
$$

where $\omega=\sqrt{k^{2}-n^{2}}$.

Having an analytical solution of the motion differential equation of a stationary turbine, the procedure for finding the best estimate of the mass flow rate of a liquid can be constructed as the following (Fig. 2):

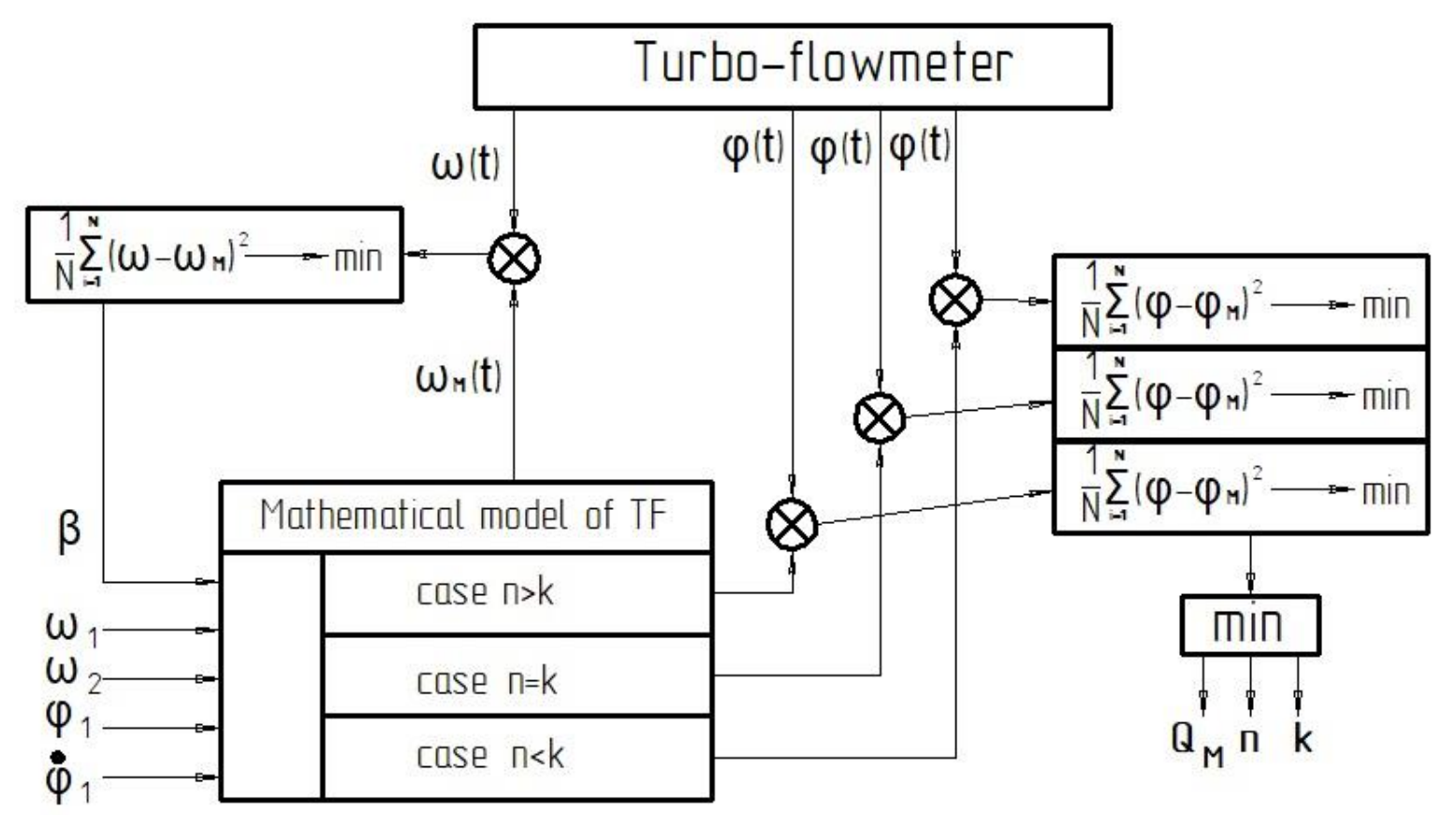

Fig. 2. Mathematical model of the flowmeter - analytical solution of the equation of motion

- equip the excitation turbine with a speed sensor; find the best estimate of the parameter $\beta$ by minimizing the sum of the "residuals" squares of the indicated angular velocity $\omega(\mathrm{t})$ and its mathematical model $\omega_{M}(t)$;

- organize three channels for comparing the real motion of a stationary turbine $\varphi(\mathrm{t})$ and its mathematical model $\varphi_{M}=\varphi_{M}(t)$;

- these mathematical models have different structure and only one of them corresponds to the real motion of a stationary turbine (its sum of "residuals" squares is minimal);

- an estimate of the mass flow rate $Q_{M}$ in the case of a minimum of the "residuals" squares sum will be the result of the stated problem solution. 
The algorithm based on the exact solutions of the stationary turbine differential equation (see expressions (13), (14) and (15)) is the advantage of the considered flow estimation scheme. The disadvantages are their relative complexity and cumbersomeness. The basis of the estimation algorithm is not analytical solution, but the result of machine integration of the stationary turbine motion equations (Fig. 3). In this case, the integration result of equation (12) is compared with the real motion of $\varphi(t)$ for all possible values of $Q_{M}, k, n$. The defined three parameters correspond to the minimum.

"Residuals" will be the true result.

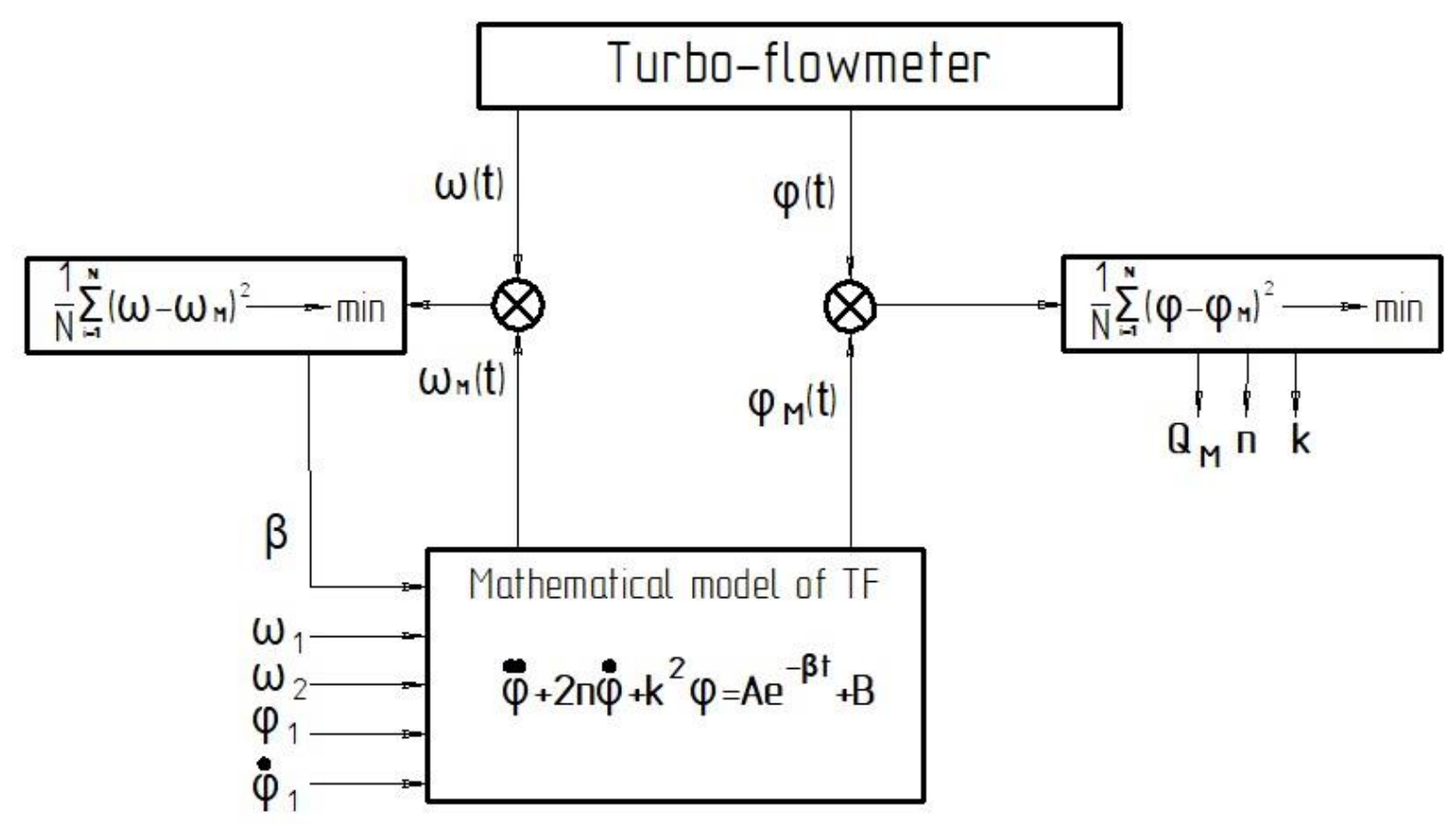

Fig. 3. Mathematical model of the flowmeter - the differential equation of its motion

\section{Conclusions}

A method for the accuracy increasing of a turbo-flowmeter by eliminating the errors associated with the presence of constant frictional moment in the suspension axes of the indicator turbine and the elastic element parameters instability is suggested in the article. The method requires minimum design completions of the flowmeter. It is based on the simultaneous parametric identification of the angular velocity of the power turbine rotation and the rotation angle of the indicator turbine. Machine simulation is carried out according to the scheme shown in Fig. 3. It confirms the operability of the proposed method. 
68

Literature

1. Кремлевский П. П. Расходомеры и счетчики количества веществ: Справочник: Кн.2/ Под общ. ред. Е. А. Шорникова. - 5-е изд., перераб. и доп. - СПб.: Политехника, 2004. - 412 с.

2. Авторское свидетельство СССР № 1040337, заявл.07.07.1981, опубл. 07.09.1983, бюл. №33. Турбосиловой расходомер, авт. Л. А. Камышев, Н. В. Люкевич, И. В. Мохорев; G01F 1/12.

3. Безвесільна О. М. Витратометрія та витратоміри: Монографія / О. М. Безвесільна - Житомир: ЖДТУ, 2011, - 220 с.

4. Палійчук Р. Ф., Биков Е.Б., Федоров В.М. Про можливість збільшення точності турбосилового витратоміра. Тези доповіді XIX Міжнародної молодіжної науково-технічної конференції «Людина і Космос», Дніпро, 12.04.2017. 